2. To: (Receiving organization)

327 Projects

5. Proj./Prog./Dept./Div.:

19340

8. Originator Remarks:

For Approval and Release.
3. From: (originating organization) 327 Projects

6. Design Authority/ Design Agent/CogEngr.:

1. eor $616: 90$

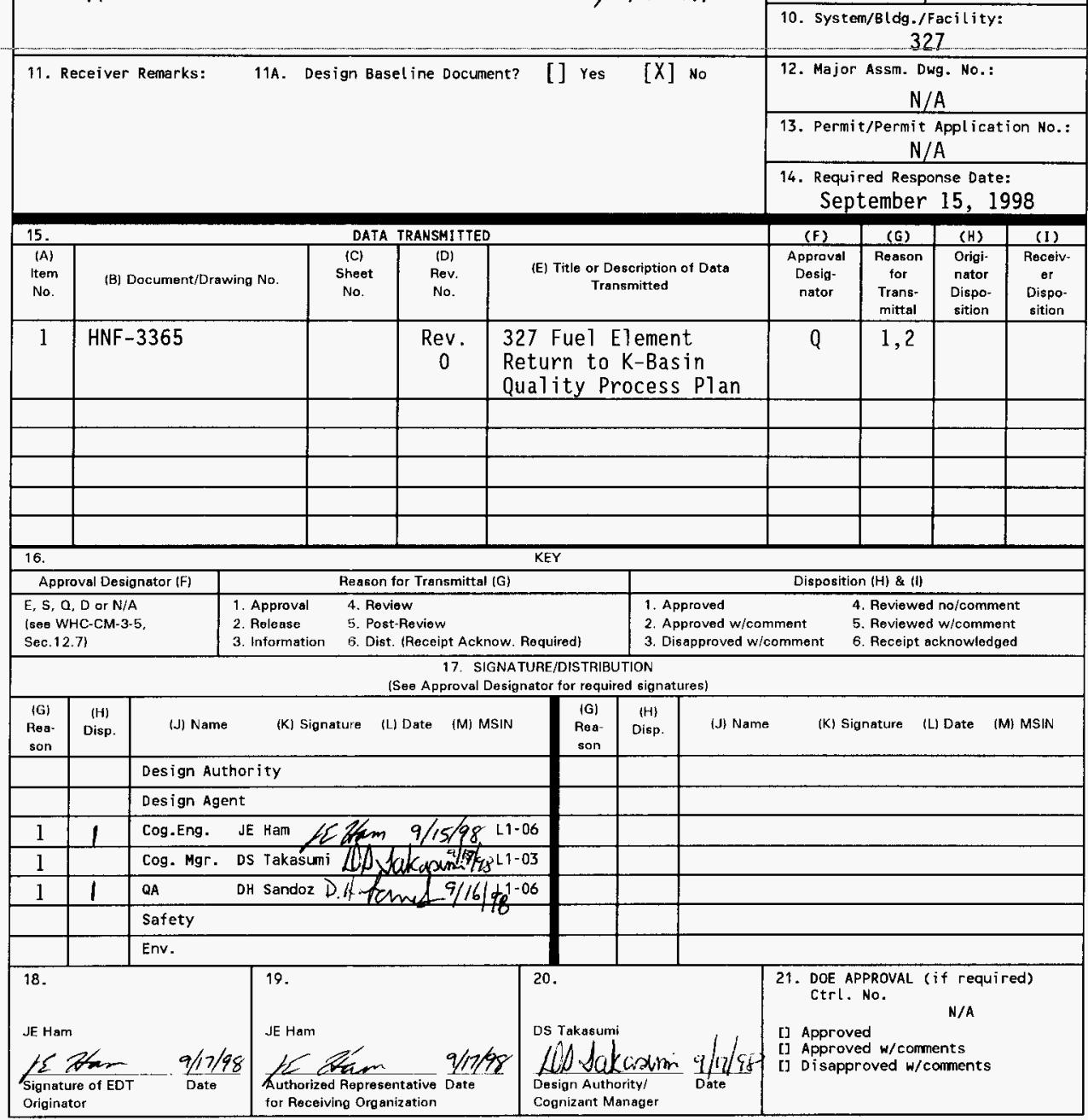


HNF-3365, Rev. 0

\section{SNF FUEL RETURN TO K-BASIN QUALITY PROCESS PLAN}

\section{J.E. Ham}

Babcock and Wilcox Hanford Co., Richland, WA 99352

U.S. Department of Energy Contract DE-AC06-96RL13200

EDT/ECN: 616490

UC: 513

Org Code: 19340

B\&R Code: EW7002010

Charge Code: K4M11 (HAN98200)

Totail Pages: 5

Key Words: 327 Facility, SNF Fuel Element Return, K-Basin, 105-KE, Chem Nuc, CNS 1-13G, Cask

Abstract: The B\&W Hanford Company's (BWHC) 327 Facility, in the 300 Area of the Hanford Site, contains Spent Nuclear Fuel (SNF) single fuel element canisters (SFEC) and fuel remnant canisters (FRC) which are to be returned to K-Basin. Seven shipments of up to six fuel canisters will be loaded into the CNS 1-13G Cask and transported to 105-KE.

IRADEMARK DISCLAIMER. Reference herein to any specific comercial product, process, or service by trade name, trademark, marufacturer, or otherwise, does not necessarily constitute or imply its endorsement, recomendation, or favoring by the Unitad states Government or any agency thereof or its contractors or subcontractors.

Printed in the United States of America. To obtain copies of this document, contact: Document Control Services, P.O. Box 950, Mailstop H6.08, Richland WA 99352, Phone (509) 372-2420; Fax (509) $376-4989$.
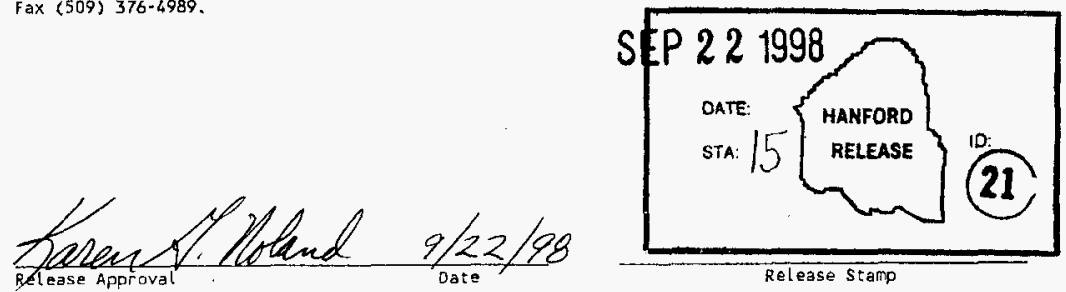


\subsection{PURPOSE}

The purpose of this Quality Process Plan is to ensure appropriate and effective quality assuring activities have been built into the work controlling documents and procedures.

\subsection{SCOPE}

The scope of this project is to return the Spent Nuclear Fuel (SNF) single fuel element canisters (SFEC) and fuel remnant canisters (FRC) from the 327 Building to the $105 \mathrm{KE}$ Storage Basin via the CNS 1-13G Shipping Cask. The CNS 1-13G is a commercially owned cask which has been leased for use on the Hanford Site. A cask insert (liner/rack) will be used to hold up to six fuel canisters at one time inside the cask. The insert will be added to the cask prior to loading fuel canisters.

K-Basin will determine the fuel canisters for each shipment and provide written authorization prior to loading. K-Basin will also provide time/duration calculations for the sealed cask to ensure hydrogen gas limits will not be exceeded. A safety evaluation for packaging (SEP) has been written to allow use of the cask beyond the evaluations identified in the certificate of compliance $(\mathrm{CoC})$ provided with the cask. The SEP was evaluated for the transport of up to six fuel assemblies (inner plus outer elements within canister) per shipment, using a cask insert.

Major activities for returning the fuel canisters include: receiving the cask, preparing and loading the fuel canisters, and loading shipping the cask to $105-\mathrm{KE}$.

\subsection{OVERVIEW}

The described activities will be performed under the standard operating procedure 3M-SOP-PTL-057, Receiving, Loading or Unloading, and Shipping CNS 1-13G Vertical Casks, and its supporting procedures. Babcock \& Wilcox Hanford Company (BWHC) will be responsible for the preparation and loading of the fuel cansiters into the CNS 113G Cask. DynCorp TriCities will provide transportation, and crane \& rigging support. Duke Engineering \& Services Hanford, Inc. maintains ownership and management of the fuel, including coordination with Waste Management Federal Services, Inc., NW Operations (WMNW) for the preparation of shipping documents, scheduling road closures, and providing necessary inspections and oversight to ensure compliance with D.O.T. requirements. 


\subsection{PROCESS PLAN}

\section{RECEIVE CNS 1-13G CASK}

The CNS 1-13G Cask will be delivered to the Hanford Site, and receipt inspected to verify it's acceptance for use in transporting SFECs. The cask will be transported empty to the 327 Building. After a radiological receipt inspection has been performed by an RCT, Crane \& Rigging Services will remove the over-pack and place it in a lay-down area outside of the building. The cask will be moved into the truck-lock and surveyed again. Once surveyed, removed from the truck and transferred to the small basin, the cask will be opened and prepared for loading.

\section{PREPARING AND LOADING THE FUEL CANISTERS}

Each fuel canister authorized for shipment will be transported one at a time from the large basin to A-Cell via the small basin. The fuel canister identification label will be verified, and the gas trap removed. The fuel canister will be transported to the CNS 1$13 \mathrm{G}$ Cask and placed inside. This evolution will occur for each authorized fuel canister, up to the allowed six.

\section{SHIPPING THE CNS 1-13G CASK}

Once loaded with fuel canisters, the cask will be decontaminated, drained and sealed for shipment. The cask will be returned to the truck-lock, surveyed and loaded back onto the truck. It will be moved outside, over-packed, and surveyed again. The proper shipping documents will be completed and the cask will be transported to K-Basin for unloading. The cask will be unloaded by K-Basin personnel and returned for the next shipment. 
Table 1

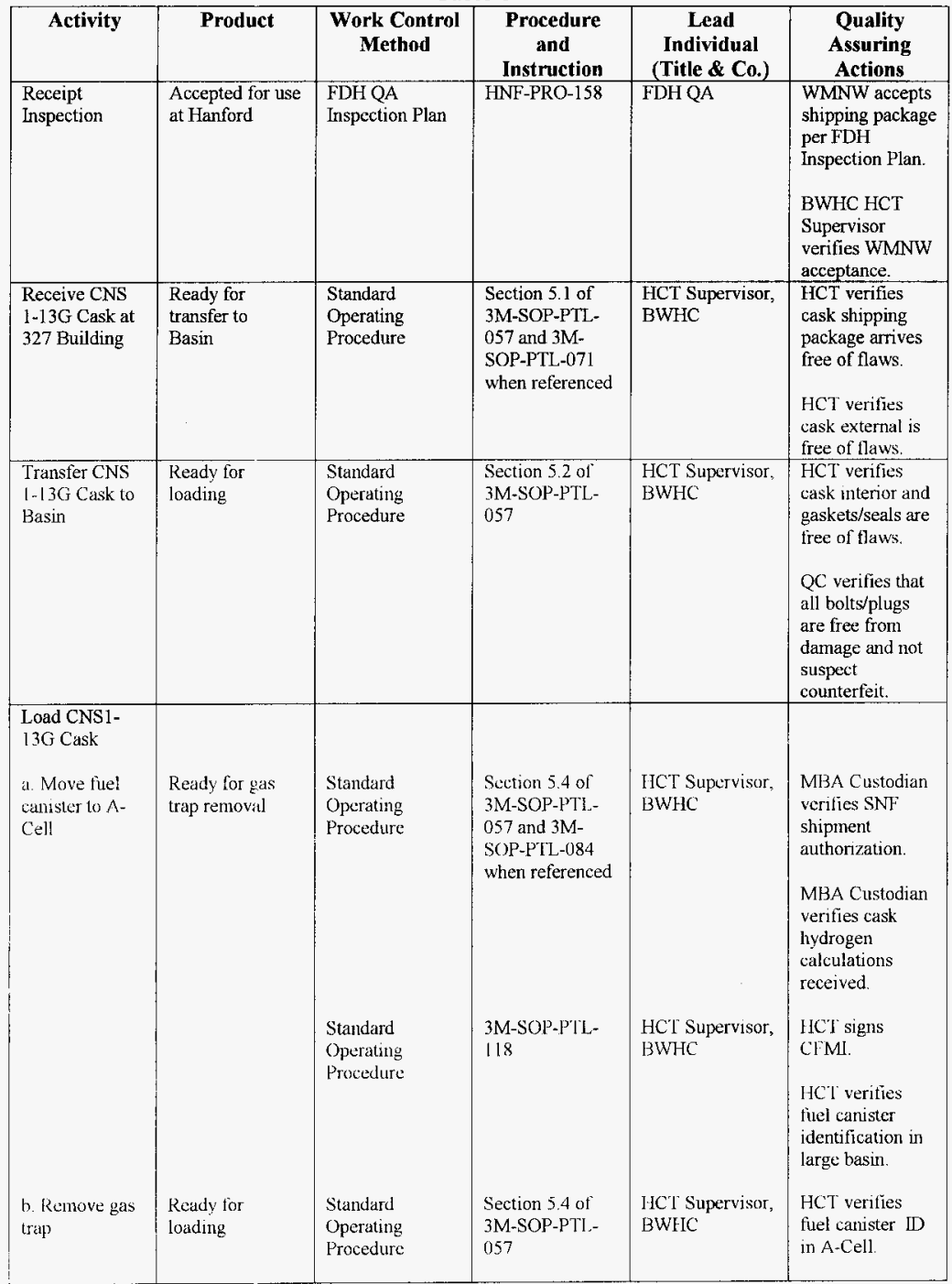




\begin{tabular}{|c|c|c|c|c|c|}
\hline $\begin{array}{l}\text { c. Load fuel } \\
\text { canister }\end{array}$ & & $\begin{array}{l}\text { Standard } \\
\text { Operating } \\
\text { Procedure }\end{array}$ & $\begin{array}{l}\text { 3M-SOP-PTL- } \\
118\end{array}$ & $\begin{array}{l}\text { HCT Supervisor, } \\
\text { BWHC }\end{array}$ & $\begin{array}{l}\text { QC verifies fuel } \\
\text { canister } \mathrm{D} \text { in A- } \\
\text { Cell. } \\
\text { HCT signs } \\
\text { CFMI. }\end{array}$ \\
\hline $\begin{array}{l}\text { Prepare CNS 1- } \\
13 \mathrm{G} \text { Cask for } \\
\text { shipping to } \\
105-\mathrm{KE}\end{array}$ & $\begin{array}{l}\text { Ready to } \\
\text { Ship }\end{array}$ & $\begin{array}{l}\text { Standard } \\
\text { Operating } \\
\text { Procedure } \\
\text { Standard } \\
\text { Operating } \\
\text { Procedure }\end{array}$ & $\begin{array}{l}\text { Section } 5.5 \& \\
5.6 \text { of } 3 \mathrm{M}-\mathrm{SOP} \text { - } \\
\text { PTL-057 } \\
\text { 3M-SOP-PTL- } \\
118\end{array}$ & $\begin{array}{l}\text { HCT Supervisor, } \\
\text { BWHC } \\
\text { HCT Supervisor, } \\
\text { BWHC } \\
\text { HCT Supervisor, } \\
\text { BWHC }\end{array}$ & $\begin{array}{l}\text { Procedure step. } \\
\text { HC1 signs } \\
\text { CFMI. } \\
\text { BWHC QC } \\
\text { approves } \\
\text { completion of } \\
\text { procedure. }\end{array}$ \\
\hline
\end{tabular}




\begin{tabular}{|c|c|c|c|c|c|c|}
\hline \multicolumn{7}{|c|}{ DISTRIBUTION SHEET } \\
\hline To & \multirow{2}{*}{\multicolumn{2}{|c|}{$\begin{array}{l}\text { From } \\
327 \text { Projects }\end{array}$}} & & & \multicolumn{2}{|c|}{ Page 1 of 1} \\
\hline Distribution & & & & & \multicolumn{2}{|c|}{ Date $09-15-98$} \\
\hline \multicolumn{5}{|l|}{ Project Title/Work Order } & \multicolumn{2}{|c|}{ EDT No. 616490} \\
\hline 327 SNF Fuel Return to K-Basin & Quality & Process & Pran & & \multicolumn{2}{|c|}{ ECN No. $\quad$ N/A } \\
\hline Name & & MSIN & $\begin{array}{c}\text { Text } \\
\text { With All } \\
\text { Attach. }\end{array}$ & Text Only & $\begin{array}{l}\text { Attach./ } \\
\text { Appendix } \\
\text { Only }\end{array}$ & $\begin{array}{c}\text { EDT/ECN } \\
\text { Only }\end{array}$ \\
\hline $\begin{array}{l}\text { RP Bodeau } \\
\text { TL Erickson } \\
\text { JE Ham } \\
\text { KA Hedquist } \\
\text { SH Norton } \\
\text { DH Sandoz } \\
\text { RW Stevens } \\
\text { DS Takasumi } \\
\text { Central Files }\end{array}$ & & $\begin{array}{l}\text { L1-03 } \\
\text { L1-03 } \\
\text { L1 } 1-06 \\
\text { L1-03 } \\
\text { L1-02 } \\
\text { L1-06 } \\
\text { L1-03 } \\
\text { L1-03 } \\
\text { B } 1-07\end{array}$ & $\begin{array}{l}X \\
X \\
X \\
X \\
X \\
X \\
X \\
X \\
X\end{array}$ & & & \\
\hline
\end{tabular}

